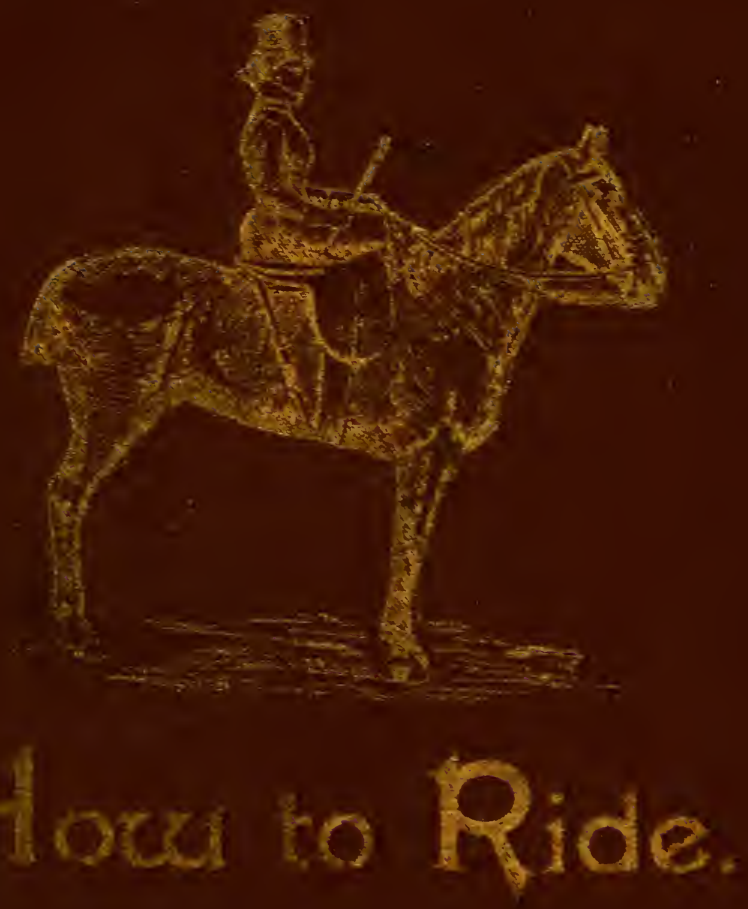




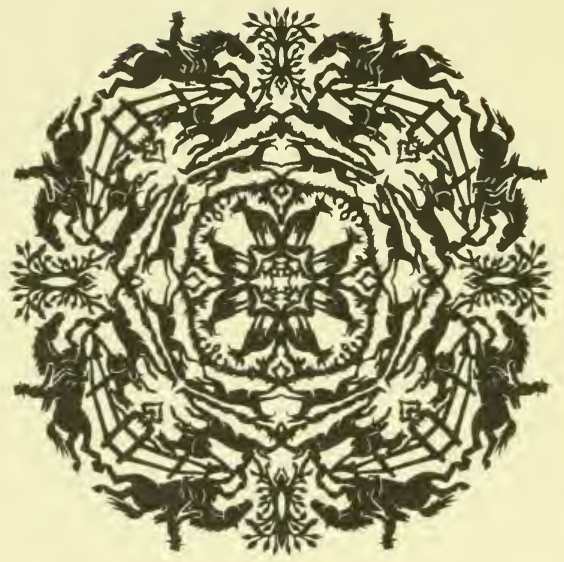

JOHN A.SEAVERNS 


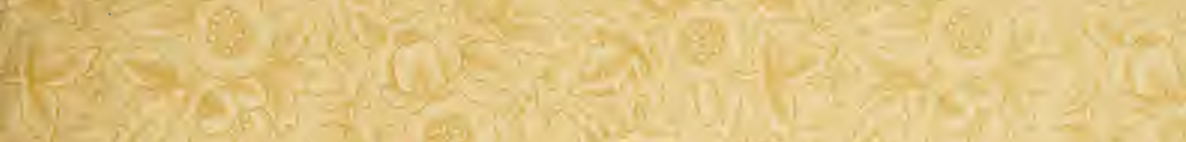
mit

$$
\text { ation }
$$






\section{How to Ride.}

BY

Thomas Clakk. 
Copyright, I891, by Thomas Clark.

All rights reserved. 



\section{PISER \& RLSSELL, PUBLISHERS, 212 East 125th Street, NEW IORK.}




\section{PREFACE.}

IT is not my intention in these few pages to try and convince the public that merely by reading some books on horsemanship, they can become expert horsemen or horsewomen ; far from it, but what I do say, is this, that if any one cares to read this little volume, and will remember the advice given in it, I feel sure that it will greatly aid them in the knowledge of riding.

I have given instructions for many years in Europe and America. As a child, I had more opportunity to indulge my taste, or, I may say, passion, for horses and horseback riding, than a great many others had. My father owned from sixty-five to ninety horses all the time, some of which were celebrated race horses, and one which he owned was fortunate enough to win the Grand National Race, which takes a horse out of the common to do. As we lived within a short distance of one of the best packs of hounds in England, my father always kept a standing number of hunters, so that his friends could follow the chase. A few of the best race horses my father owned, I will name here : Little Tom, Silvertail, Joe Muggins, Fireaway, Cherry Key, Mushroom, Slyboots, Ochiltree, Exeter, Highflyer, Merry Maid, Pipestalks, Banner 
Bearer, and many others, but as I was very young at that time, it would be tou hard a task for me to remember the names of all the horses my father ever owned, neither would it interest the reader.

Now, horseback riding, like some other pleasures, can be indulged in at any age, as long as a man or woman do not overtask their strength at the beginning, and I really believe that riding has done more to prolong life than any other sport, in fact, I know that it has, and all the best physicians recommend it very highly in many cases.

The Author. 


\section{CONTENTS.}

PALE

LEARNING TU MOUNT, . . . . . . . I

LEARNING TO DISMOUNT, _ _ . . . . . 9

ABOUT THE BRIDLE-EXPLAINING THE USE OF THE SNAFFLE ANU CURB, . $\quad$. $\quad$. $\quad$. 12

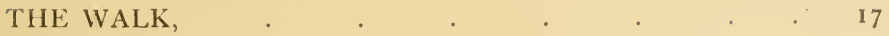

THE TROT, . . . . . . . . . . . 2 I

THE CANTER, . . . . . . . . $\quad 27$

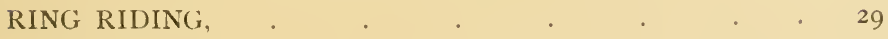

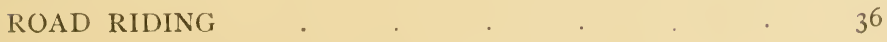

HANDS AND SEAT, . . . . . . . . 43

LEAPING-TRAINING, . . . . . . $\quad 46$

ADVICE TO LADIES AND GENTLEMEN WHO INTEND BUYING A SADDLE-HORSE, . $\quad$. 50

SUGGESTIONS-HOW TO START AND HOW TO RUN A PUBLIC RIDING SCHOOL, . . . . $\quad$. 52

WHAT HORSE-BACK RIDING HAS DONE FOR MANY

ANI WHAT IT WILL DO FOR YOU, . . . 55

SOME USEFUL TIPS, . . . . . . . $\quad 5^{8}$ 



\section{HOW TO RIDE.}

BY THOMAS CIARK.

\section{LEARNING TO MOUNT.}

After the pupil has taken a few lessons and been made acquainted with the fitting of the bridle and saddie, the next thing to do is to learn to mount his horse from the ground, as I strongly condemn mounting blocks, and as you cannot take them along with you, or find them on every roadside, it will be the best plan to learn to mount your horse from the ground.

When a man mounts his horse, he should take all the reins in the left hand, that is the right snaffle rein between the first and second fingers, the left snaffle rein held in the palm of the hand, three fingers dividing the reins, the curb reins should be held next each other, near the centre of the hand, between the second and third fingers, then place your reins neatly together, between finger and thumb, and let the end of the reins fall over towards the right side, the next thing to do, is to grasp a lock of the horse's mane with the left hand, about twelve inches from the saddle, now stand with your chest facing the left 


$$
44
$$




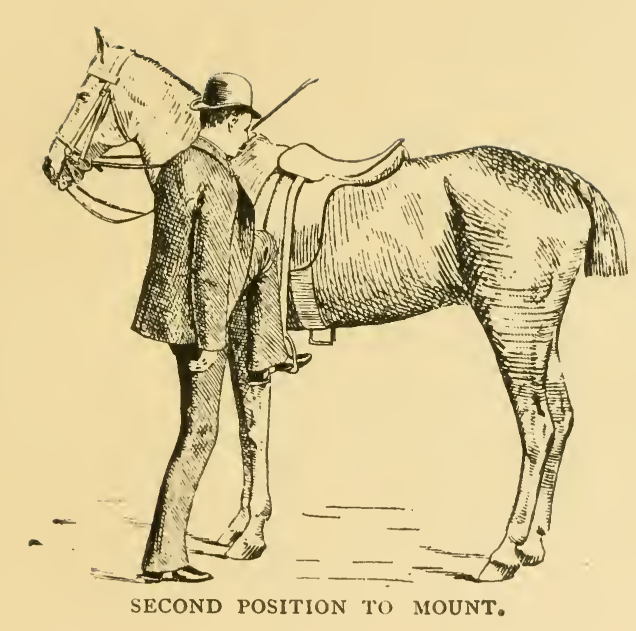


shoulder of your horse, the right foot opposite the stirrup, then take hold of the stirrup leather, just above the stirrup with the right hand, place the left foot in the stirrup as far as the ball of the foot, now take your right hand away from the leather, and take hold of the cantle of the saddle, spring up from the right foot, straighten both knees and keep the heels together, press the left knee well against the saddle before passing the right leg over. Care should be taken to keep the left foot back when mounting, so as not to touch the horse with the toe.

The pupil must sit well in the middle of the saddle, with the body upright, shoulders thrown back and chest expanded and the head raised, the elbows close to the sides, the hands from four to six inches apart, the knuckles turned out and the thumbs on the top, hands, knees and heels kept down, and the toes parallel with the horse's sides. After getting seated correctly, take the stirrups by turning the stirrups outwards, away from the horse's sides, the left stirrup to the left and the right to the right, the rider will then have the leather flat and smooth, without any twist in it.

The other method of mounting is to take all the reins in the right hand, the snaffle reins on the outside and the curb reins on the inside, that is, a rein for every finger, the rider must stand facing the saddle, then turn half left and place the right hand on the pommel of the saddle, carry the left hand nine inches in advance of the right, taking a firm hold of the mane, place the left foot in the 


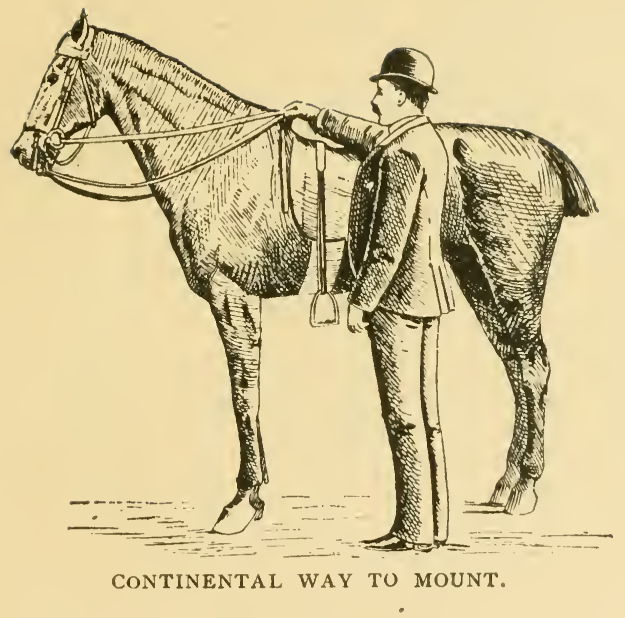




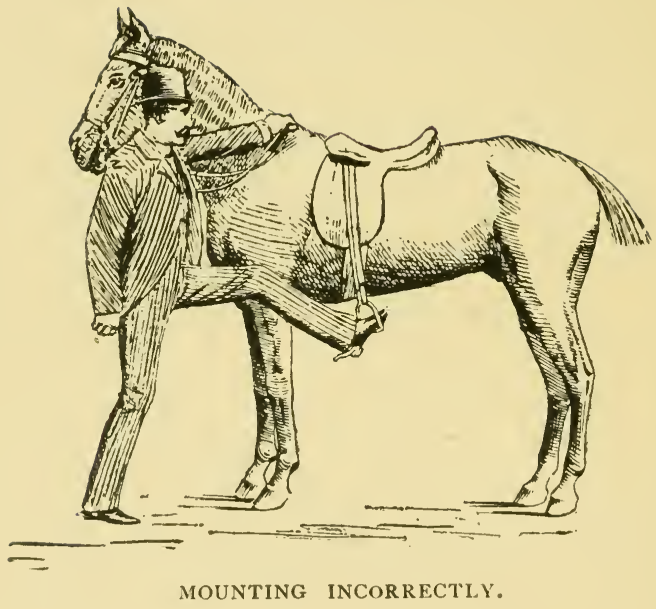


stirrup, spring up lightly in the saddle, and after you are seated firmly, change the reins from the right hand to the left.

Naturally, the ways I have described, are very hard for a beginner at first, but they should be practiced a great deal after riding a few times. Of course at first the teacher should allow you a little more length and reach, especially if one is very stout, or at all stiff, which beginners generally are at first, but plenty of practice will knock all the stiffness out of a man, if he keeps right at it, as he should do. The first method I described to you, with regard to mounting, is called the English way, and so it is, if done correctly, but most horsemen stand in front of the horse's shoulder, instead of nearly back of it, and as the man's arm is not long enough to reach the saddle, consequently he has to hop on the right foot, near enough to the horse to reach his saddle, it is not only an extra exertion on his part, but it annoys the horse and causes him to become restless and unsteady while mounting. The second way of mounting a horse is called the military or French way, and is taught a great deal in the United States, and for some reasons I prefer it to the other way, but one must be careful not to stand too far back, for fear that the horse might at some time strike the rider in the back from behind. Some horses are very restless to mount, and commence pawing with their front legs with impatience to be off, and sometimes from nervousness or fright, and that is one more good reason why the 
rider, when mounting the English way, should stand back of the horse's shoulder, instead of nearly in front of it as a great many do. 


\section{LEARNING 'TO DISMOUNT.}

So far as you have been told how to mount, now I shall explain to you how to dismount. There are two different ways. The first way is to keep all the reins in the left hand and grasp the mane, place the right hand on the pommel of the saddle, take the right foot out of the stirrup and then cross the leg over the back of the horse, and at the same time bringing the right hand well in the rear of the saddle, now bring the right foot to the ground before taking the left foot out of the stirrup. The other method to dismount, is to change the reins from the left to the right hand, resting the right hand on the pommel, grasp the mane with the left hand, passing the right leg over to the left side, then throw the left shoulder back, step down to the ground with the right foot, discard the left foot from the stirrup, advance one yard to the front, and then stand to your horse, holding the snaffle rein only. There are three ways to adjust your stirrups, the first way is to measure your stirrup by the length of the arm, that is, place the stirrup under the elixir of your left arm, then extend your arm to its full length, allowing the tip of the second finger to touch the centre of buckle of the stirrup leather. The next test is to get mounted on your horse and press your feet well down, sitting well in the middle of the saddle, raise the toes and then measure the stirrup with each ankle, the steel should just touch 
each ankle. The third way is to place your feet in both stirrups, keeping them under the ball of each foot, and take care to sit well in the centre of the saddle, now stand straight up in your stirrups, resting the back of the right hand on the pommel of the saddle, if you can clear the pommel with the right hand resting on it, you have the stirrups the correct length. The second and third ways are the best to follow; the first way will do in some cases, but not in all, you will understand that a great many men have long backs and short legs, while others have the reverse; then again, one's arm may not be as long as one's leg, and on some horses you will require different lengths of stirrups. A lady should learn to mount her horse from the ground, and insist on being taught that way, and also learn to dismount without any assistance whatever.

To mount correctly, the lady should take hold of the four reins in the right hand, place the hand on the up pommel then place the left foot in the hand of the assistant, resting your left hand on his shoulder; at the word three, straighten the left knee, at the same time spring up with the right foot on to the saddle, cross your right knee over the upper pommel, place the foot in the stirrup, then change the reins from the right hand to the left. The way to dismount, is to hold the reins in the left hand, take the foot out of the stirrup, pass the right leg over the pommel, with the assistance of the right hand placed under the right knee, to prevent the skirt from gretting caught on 


\section{LEARNING TO DISMOUNT.}

the pommels, then change the reins from one hand to the other, now turn your body round facing the horse, holding the right shoulder well back, hold the skirt up to your waist with the left hand, then slide gracefully down, but do not attempt to jump off. When dismounting you should have the right snaffle rein drawn up a little shorter than the left one. A good horsewoman should be able to dismount at a walk, at a trot, and when going at a slow canter, and by practice and by following out proper instructions, it can be accomplished without any danger to the ricler. 


\section{ABOUT THE BRIDLE - EXPLAINING THE USE OF THE SNAFFLE AND CURB.}

BEFORE proceeding any further with my book, I should like to call the reader's attention to the bridle and saddle which one has to use on the horse, and explain to you the use of each bit separately; speaking about the snaffle first, and then saying a few words with regard to

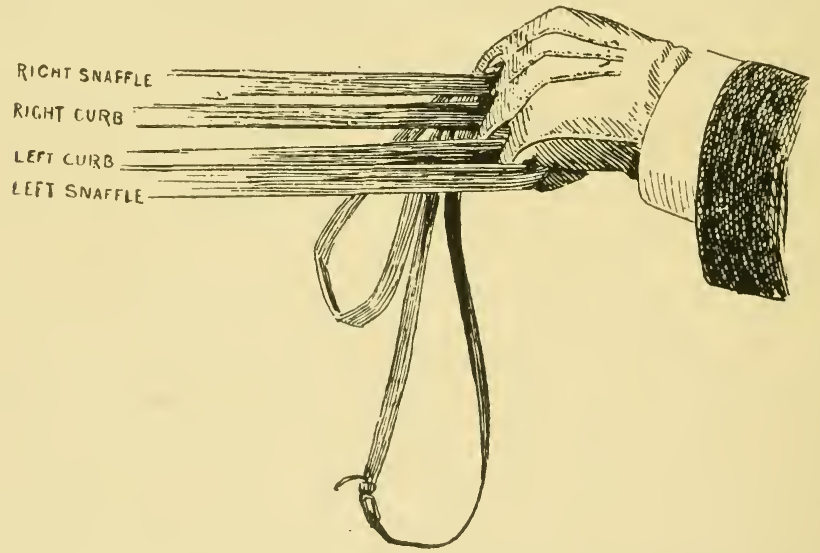

the curb bit and curb chain. Now it is necessary when riding a horse, to have a well fitted riding bridle on him. Properly speaking, the bridle should have a light cavesson or noseband, and that means three headstalls, but never less than two, if you have only two, the best plan 
is to run the noseband through the curb headstall, with the snaffle headstall passing on the outside.

The snaffle I will call the acting bit. The curb bit, I think it will be well to term the lever or balance bit. I will now speak about each bit separately. The snaffle is the upper bit, with a round ring on each side, and when rightly placed in the horse's mouth, should fit easy without gagging, and it comes much more in use for a beginner than the curb does. If you wish the horse to walk

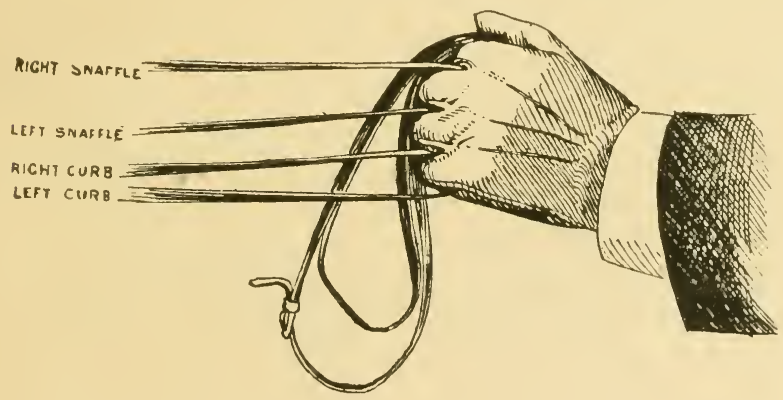

out freely, use the snaffle, use the snaffle to trot a horse, and use the snaffle when you jump a horse as well as the curb, and above all, in the latter case, use your best judgment. Now I come to the curb bit. The bit, when properly placed in the horse's mouth, should be one inch above the lower tusk, and in a mare's, two inches above the mark. Sometimes it will be necessary to have the bit or mouthpiece a trifle higher or lower, as the con- 
formation of some horse's mouths differ a great deal. I have simply written down the greneral rule to go by, which will answer in most cases, but not in all. The lower the bit is placed, the more severe it is. Great care must be taken that the width of the mouth piece is neither too wide nor too narrow for the horse's mouth, or it will injure the horse, and bad results will come from it. Sometimes the bit is placed very high in the horse's mouth, so it will be as well to look at your bridle and saddle before mounting, and see that every thing is in perfect order.

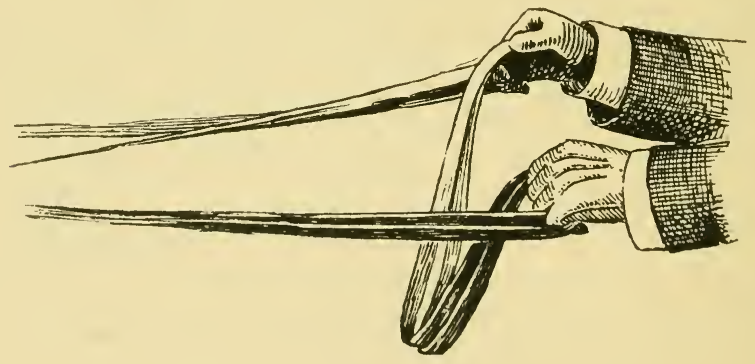

The correct place for the curb chain is in the chin groove, and when properly adjusted one should always be able to place the first and second fingers under it. The chain should lie smoothly, without any twist in it, and care should be taken not to place the chain. too high, that is on the cheek bones, for it will not only annoy the horse, but will make him thrust out his nose, instead of bringing 
it in, as he should do. On some bits, the length of the curb chain should not be more than nine inches. No curb should be placed on any horse that has not been broken to answer and bend to the pressure of it, as oftentimes more harm than good will come from it, very probably some accident. The throat lash should be loose enough to admit the hand through, the breastplate should fit easily, so that one can pass the hand between the breast and leather. The girths of a lady's saddle, when properly strapped up, should admit three fingers, and that of a man's saddle four.

The reader may like to know how to distinguish the snaffle reins from the curb reins; you have been told how to distinguish one bit from the other, and now I will explain to you how to know one rein from the other. The snaffle rein is the upper rein, and has a buckle in the centre, and is held outside. On some bridles the snaffle rein is wider. The reason for having a buckle on the rein, is to be able to part the reins quickly when you desire to use a ring martingale. The curb rein is the lower rein, and is sewn at the centre. It is held inside, that means nearly in the middle of the hand, between the second and third fingers of the left hand.

Having mentioned a martingale in this chapter, I might as well speak a few words with regard to them. The only martingale that should be used on a saddle horse is a ring martingale, and then let it be a running one, as all other martingales are useless and dangerous. 
Horses that are properly trained and ridden, should require no martingale, and the less trappings a horse has on the better he looks. 


\section{THE WALK.}

To make a horse walk forward, you should ease on both reins and close both legs equally. If a lady is riding she should press her left leg behind the girth and use the whip on the right side. The whip or crop to a lady acts in the place of the right leg, and a horsewoman should never ride without one. The front legs of the horse are the bearers or supports, the hind ones the propellers, and are more or less relied on in the canter, and especially in jumping. Now, the rider's hands are for the forehand of the horse; all that part in front of the saddle, and the legs, are to control the haunches, all that part back of the saddle. The hands and reins are intended to guide and steady the horse, and to stop him when required, and the legs are used to make the horse go forward, they help to balance and support him, and riders should never use one without the other. A carriage horse guides from the bit alone. A saddle horse should be guided, partly from the neck, which is termed bridlewise, as well as from the bit, and by the aid of either leg. When riding in company, never chirp or click to your horse, as it is a very rude habit, as you may unsettle your friend's horse, if it is at all a lively animal. Instead of chirping to your mount, touch him with a pressure of the leg, and make him ex- 


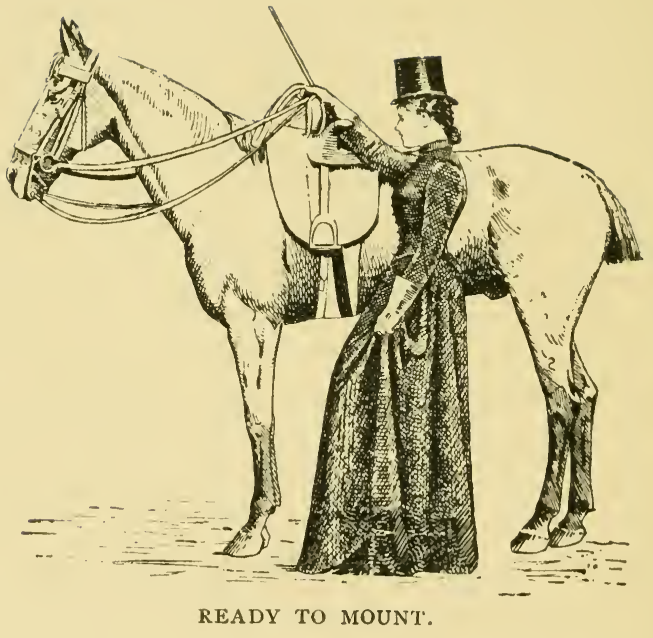


tend his walk. I do not know of anything so annoying as to see a horse creeping along, as if the poor animal had corns and could not travel any faster, because the horse's gait should be always active and decided. Now often it is the fault of the rider, and not the horse at all. If you will give the horse his head, and make use of the leg and whip, he will do his best to walk out in' the right manner. You should be careful when riding to keep your left hand firmly closed, in fact, make a fist of it, and wear a loose-fitting glove, an extra size will be all the better, and it will be well to dispense with rings when riding. I remember an instance of a boy riding on a pony down a steep hill at a walk on the hard road, and when about half way down, the pony stumbled, fell, and broke his knees; if the lad had had his hands firmly closed, the reins would not have slipped through his fingers, but in all probability he could have pulled up the pony before harm was done, but that is not all, for if you do not hold the reins firmly, you will keep getting a longer rein than you require, and if the hand is not closed it will necessitate your shortening them very frequently. 


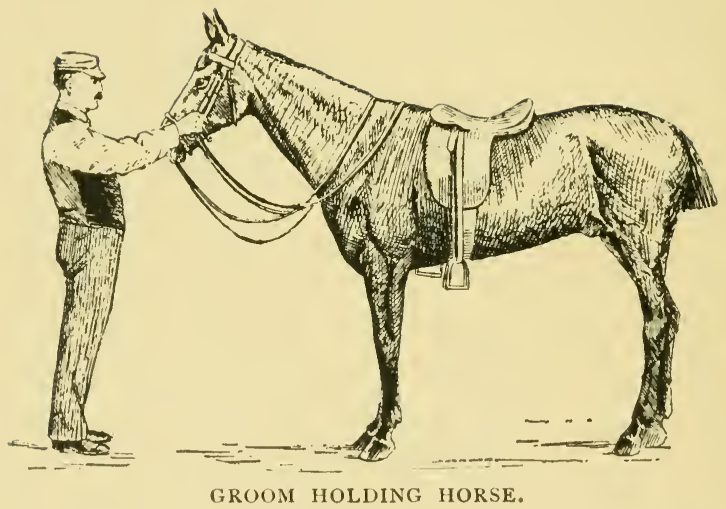




\section{THE TROT.}

There are a great many riders in the United States who have never been able to ride a trotting horse, and could not if they would, and they have seldom wished to try, as they have found it too much labor. In the western countries, and in the south, a great many ride on horses at the single foot, pace, lope or canter, and on some horses the various gaits are easy and pleasant, but there is no gait so enjoyable to ride as the trot, when any one knows how, and being harder to learn than any other, it is more enjoyable when mastered. It is one rule by which a teacher can tell a good rider from a bad one, but I do not wish my readers to misunderstand me, and think that if they are able to sit on their saddle correctly, and rise gracefully in the trot, and just catch the stride of the horse and rise in good time, that they are accomplished horsemen or horsewomen, for I must ask you not to think any such thing; to make a good rider, one has to know and understand many more things, as well as to be able to sit well on a trotting horse.

I shall first explain to you how to make a horse trot. You should ease on both reins and close both legs, according to the horse's temper, and when a lady is riding, she should touch her horse with the whip behind the saddle 
and close the left heel, then when the horse is trotting, the rider should feel the reins to raise the horse's forehand and to keep his haunches under him.

It is very likely that some of my readers may not understand the advice given above, so I will explain to you clearly what I do mean. Now every horse has a different gait, mouth and temper; some horses are pullers, while others you must ride light in hand, then again, you will find horses that are free and ambitious, while others are lazy and require urging. When I say ease on the reins, I mean for you to give the horse a loose rein, and not to prevent him from going in any way, and when I say feel the reins, I mean that you are to hold him in to some extent and not allow him to go at whatever gait or rate of speed which he prefers. You must make up your mind to let your horse know that you, and you alone, are master or mistress of your mount. If you are firm at the start, you will be able to do anything with him, and when you once get full control over your horse, it will help you a great deal before you get through with horseback riding.

The first thing to do when mounted, is to try and get a correct position on the saddle. Some ladies, after they have been riding for some time, have a tendency to ride onesided, or ride with a churning movement; raise their hands, hold their heads down and swing their legs about like the branch of a tree when the wind blows hard, or like the pendulum of a clock, foot well home in the stirrup, 


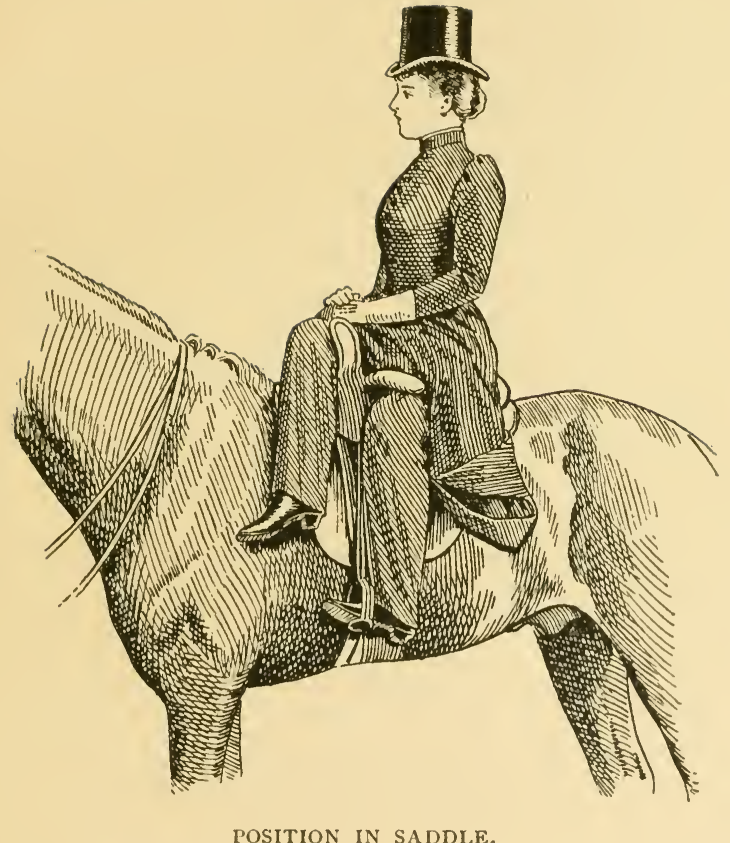

POSITION IN SADDLE. 
toes down and turned outward very much, with plenty of space between the knee and saddle, at the same time not forgetting to pull with sudden jerks on the reins. Such riders even declare afterwards that " it was just too lovely for anything."

Now all the above faults can be prevented if the pupil has a good teacher and will take pains to learn how to ride. When trotting the rider must not depend on the stirrup alone, but must rise from the right knee, the right toe kept down close to the horse, keep the left heel down, with the stirrup on the ball of the foot, care must be taken that the left foot is not drawn back or thrust forward, but held straight down, the toe nearly in line with the left knee. If the foot is drawn back, the rider will be thrown forward, and if it is thrust forward, the pupil will rise in a stiff and unnatural way. It should always be remembered that the limbs support the upper part of the body. The rise and fall in the saddle should be straight, easy and graceful, without bending the body forward, and in perfect time with your horse; bear in mind that it is entirely wrong to attempt to rise when the horse is walking, jog trotting or cantering, and the rider must keep a close seat until the horse trots fast enough to assist the pupil to rise. If pupils try and attempt to rise before the horse attains the rate of speed that is required, it gives any one an impression that the rider desires to lift his or her horse up from the ground, which is not only wrong, but very foolish. A lady when riding, must try at first to get a good 
seat, that is, sit down well in the centre of the saddle, sitting square to the front, with the buttons of your waist in a line with the horse's mane, and the shoulders in line with the horse's ears, with the shoulders thrown well back and elbows carried close to the sides and the head held up, looking well in front of you for twenty yards or so. Now when wishing to bring a horse down from a trot to a walk, do not keep rising, but after slowing your horse down to a slow trot, take a close seat, for if you keep rising and the horse should stop very suddenly, it is more than likely that you might be thrown off. 


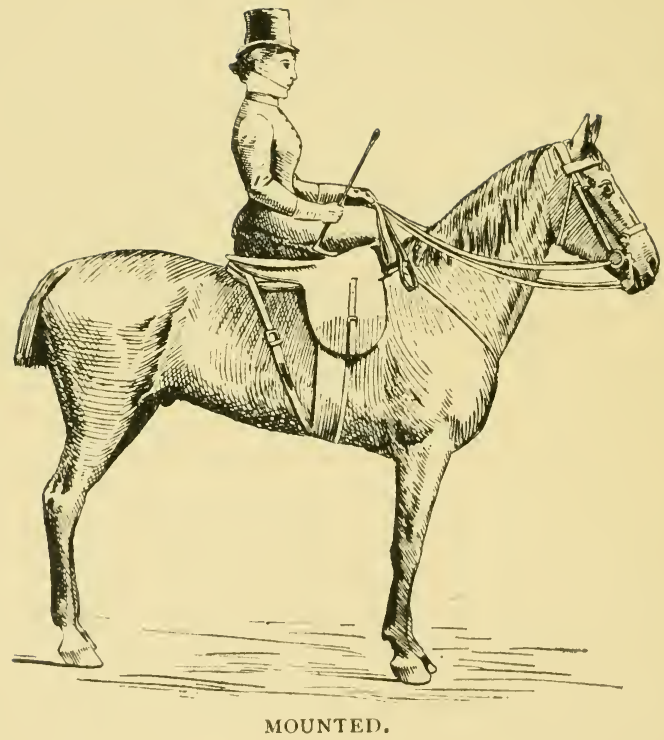




\section{THE CANTER.}

IT is a hard task for a great many riders to make a horse canter correctly, and still more difficult for others to canter at all. Even some men ride, hit or miss, all their lives, without knowing right from wrong, and care less, as long as the steed they bestride, carries them along at a rapid gait. The great trouble is that some riders do not know how to place a horse for the canter, and very seldom what aids to use. When a horse canters properly, the weight must depend on the haunches, and the horse must balance himself accordingly; for instance, if the rider is riding in a ring, and riding to the right, the animal should by all means lead with the right leg, both front and rear, and vice versa to the left. When riding to the right the horse obtains his balance on the right hind leg, assisted by the left hind leg; when riding to the left, it is the left hind leg, assisted by the right hind leg. Now at first, when you learn to canter your horse, you should do it from a trot, as it is easier for the pupil. The aid for cantering is to try and raise the forehand, use a strong pressure of both legs, the outward one much the stronger. When riding in the right direction, the rider should raise the right rein and close the left leg, and when riding to the left, should raise the left rein and close the right leg. 
You must at all times have your horse well in hand and fully collected, and try and make your horse canter nearly as slowly as he would walk. You should bring the horse well in balance by a steady support with the reins and legs. The horse should at all times be so placed that he looks the way he is going, and if the rider cannot make the horse canter on straight lines, he will be able to do so on a circle, or on turning a corner. When you have been riding for some time, it will be well for you to start your horse in a canter from a walk, and also from a halt. You should collect your horse with the curb rein, and stimulate him with the legs and whip if required. It is necessary at all times to have the horse's head brought in and not have his nose thrust out, and one should at all times be able to feel and tell if the horse is leading right or not. If a horse is leading with the right front leg and the left hind one, then the horse is called disunited, and when a horse goes that way, he should be brought down to a walk at once, as it not only gives the rider a very unsteady and insecure seat, but it is also dangerous. Sometimes green horses get disunited, also nervous ones, but more often the blame should be attached to the ricler, as it is usually his fault. 


\section{RING RIDING.}

RiDing in a ring is one thing, and riding round a ring is quite another. How many riders when they ride in a school, make a complete circuit, the first thing they think of doing after getting mounted, is to make as much haste across the ring as they can, then dart into some corner, then dart out again, and sometimes they even charge against some other riders, and in their excitement forget to apologize, but it could be all avoided if the rider would only follow proper advice.

After a rider gets mounted on a strange horse, always make it a point to walk round the ring a few times before you attempt any quicker pace. When riding at a trot or canter, always ride your horse near the wall and do not cut off the corners, as it is a very bad habit, and it teaches the horse a very bad trick. After reining in your horse from a trot to a walk, ride your mount towards the centre of the ring, about ten feet away from the side, and above all, try and avoid riding round on a circle, but try and ride on straight lines as well as you can. It is more difficult in some respects to ride round in a ring than it is on the road, especially if you are called upon to ride circles and to do several changes. An even balance in the saddle is the most important of all, and that is what a pupil 


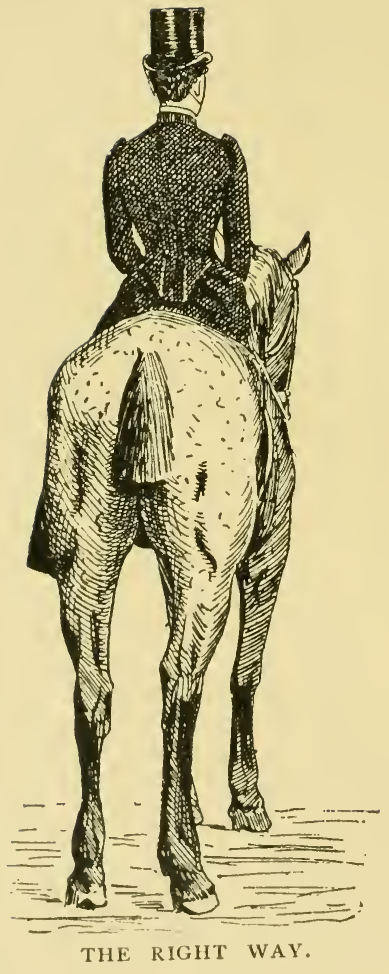




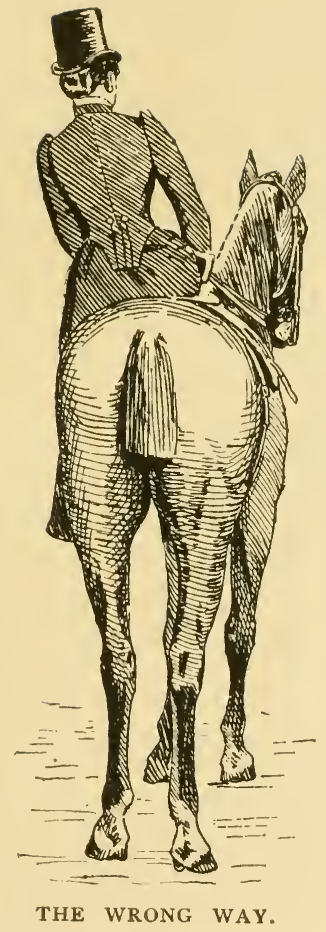


must study and practice to become an expert horseman or horsewoman. When riding on the right hand and turning a corner, be careful to lean over towards the centre of the curb you are describing, and just the reverse way on the left hand. The upper part of the body should incline to the right on the right hand, and on the left hand a lady should keep her right shoulder back and sit square to the front. One should use judgment according to the rate of speed that the horse is traveling.

Remember that when riding in a class on the lead, that it is absolutely necessary for the leader to be a good judge of pace, and to keep up an even gait, without this knowledge, a man or woman should never be over anxious to lead a class; there are also two other requirements one should know, that is to have a quick eye to take in the whole class at a glance and to be able to assist it in a measure and to be able to hear well, so that you may be able to understand distinctly the commands given by the instructor. When an order is given to change hands, you should not turn your horse left or right about, but ride across the centre of the ring, well up to the wall, and then turn left or right, as the case may be; when you change from the right hand to the left when riding in a class, and are riding at one end of the ring and wish to change to the other end, pass on the right, and when you wish to change from the left hand to the right, pass on the left; the difference in changing is this, that in changing from the right hand to the left, you pass bridle hand 
to bridle hand, whereas in passing from the left hand to the right, you do not do so.

The reason the term right and left hand is used, is because when on the right hand, the right shoulder of the horse is towards the centre of the ring, and when riding on the left hand the left shoulder is towards the centre, and in the canter the horse extends one shoulder more than the other; there are other rules given, but the above one is correct.

A great many riders in this country ride on buckskin saddles and use rubber pads. I think it a very bad habit to become accustomed to. There are some ladies who like to ride with the slipper stirrup, but I do not like it, as it teaches a pupil to ride from it. The best stirrup in the market is the Victoria Stirrup, and it pleases every one. The best way for a man to become a good rider, is to ride on the horse bareback, and also to ride on the saddle without stirrups. One must ride by natural means, not by artificial means, as it were, but try to balance yourself and to ride that way for some time without using other means. If you ride every day for a few months without stirrups, if only for a few minutes at a time, you will soon feel a great improvement in your riding. If you should be riding on a horse that you know, I think it is a very good plan to speak to him once in a while. You can often calm a highstrung horse down by doing so. I do not mean that you should speak to your horse when taking a lesson, leave that for your teacher to do, as the 
horse understands his voice better, but I mean when you are riding alone and are mounted on a lively animal which is inclined to prance and caper about out of good feeling. Do not become afraid, but use the words "steady boy," and you will find that it will calm the horse down nearly in every case. If you find that your horse seems really afraid of anything, say to him "steady boy," or "easy boy," and always speak loud enough so that he can hear you. Remember that if you are afraid of the horse, the horse is much more afraid of you.

Now I am going to speak to you about the one word "Whoa." Never say whoa to your horse without you wish him to stop; the word whoa has been greatly abused by thousands, and oftentimes it is a safeguard against accidents and runaways, so never mention the word without you wish the horse to stop, and if you own a horse teach him to understand the meaning of the word, or have him trained by some one. The word whoa is one of the greatest words in the horse language, and it means so much to all who own horses, not only to the horse, but to those who ride and drive them at times.

There are three ways to turn a horse, namely: on the centre, on the forehand, and on the haunches. When a horse turns on the centre, the four legs move round on his own ground, and when done correctly you should use both reins and legs equally, without attempting to back your horse. When you wish to turn a horse on the forehand, the haunches of the horse must be brought 
round on a circle, without the front legs leaving the ground they began at; in turning round to the right, the left front leg acts as the pivot, and in turning to the left, the right front leg acts as the pivot. The aid for turning a horse right about on the forehand is this, the right rein stays the forehand, and the pressure of the left leg circles the croup round step by step. The right leg should be kept closed, so as to prevent the horse from hurrying away from the pressure of the left, and you should retain a feeling of the horse's mouth by raising the left rein. 'To turn the forehand left about, you stay the forehand with the left rein, and use the right leg to circle the croup, the hands and legs are simply reversed. To turn a horse on the haunches, the forehand turns round, and the hind legs turn on their own ground. When wheeling to the left, it's the left hind leg that serves as the pivot, and when wheeling to the right, it's the right hind leg that serves as the pivot. In turning right about on the haunches, you should close the right leg to stay the hindquarters, and feel the right rein to circle the forehand round, and in turning left about you close the left leg and feel the left rein.

I will write just a few more words before I close this chapter on ring riding. Remember that when riding in a class, every rider should be able to trot or canter single file, each one keeping his or her horse well collected, and also be able to canter by two's or four's; each rider should be very careful to keep the proper distance. 


\section{ROAD RIDING.}

EvERY teacher knows that it is the wish of every pupil to get out on the road as quickly as possible. There are several reasons why a pupil prefers to ride on the road in preference to riding round a ring. First, it gives pupils a feeling of gratified pride and pleasure to think that they are able to guide their horses safely and with skill past so many vehicles in the park or elsewhere, without any mishap to themselves or to their horses. Secondly, they enjoy having their parents and friends meet them out, so that they can display some of their skill before them, and thirdly, every pupil finds that it is a great relief to get away from the monotony of the ring for a change, if for no other reason. Riders are perfectly right in wishing to ride on the road, for it not only improves the pupil's riding, but it gives them confidence and also improves their health. I am sorry to say that very few riders in this country strictly follow the rules that govern road riding. By the way some horsemen ride, even good riders, I doubt very much if they know the rules. The law in America is this, that when one party meets another on the road, they shall pass on the right side, but when riding on horseback, one should not only pass on the right, but also keep on the right side of the road. There are very 
few riders that do ride on the side of the road. I have seen a few hunting men do it and some thorough horsemen and horsewomen ride near the side, but they are few and far between. I have often politely asked my pupils when they went out alone to ride on the side; some have done so, but a few have exclaimed, what difference does it make on which side of the road I ride, as long as I get there. It makes a great deal sometimes to both horse and rider. I will explain the why and wherefore. The first reason why one should ride on the right side, is because it is the rule and it looks better. The second reason is that if you are riding in the middle of the road and happen to be mounted on a vicious brute of a horse, which will plunge and rear with you, or for instance one that is inclined to be balky and not willing to go one way or the other, and so by riding in the middle of the road on such an animal, you would place yourself and your horse in everybody's way who desired to pass, or probably your horse might plunge against some passing carriage, or the carriage would strike your horse, especially if the road was a narrow one, and serious results might occur, possibly a runaway. The third reason is this: that if you are riding outside the city, the ground on the side of the road is so much softer than in the centre, and it is so much better for the horse. If riders would follow my advice when riding on the road, there would not be so many horses with splints and so sore forward as their are. 
It is admitted by experts that there is much more strain on a saddle horse than a carriage horse, and one should be always ready and willing to relieve him and render his burden as easy as lay in the rider's power. You have already been told on which side of the road you should ride, now I will give you some more advice with regard to road riding. After the groom has brought your horse to the mounting-block, or from your own stable, as the case may be, before mounting, walk quietly up to him and notice if the bridle and saddle are put on to your liking, and if you own the horse yourself, ask after his appetite, and enquire from the man when he needs shoeing again, and after being satisfied with the reply, cast a look at the horse's appearance, and if you find that every thing is in order, speak a word of praise to your man before riding away. After leaving the stable be careful to walk your horse for a short distance before going at any greater speed. Notice at a glance how he conducts himself on the road. If you should be mounted on a horse that you have never ridden before, be always careful to be on the alert for any object that you think would in any way be at all likely to disturb or frighten him, and be careful to look well in front of you and keep your hands down. The next thing to do is to find out how you had better ride your horse. The proper way to ricle a horse on the road is to have a steady and easy hand, and not to worry the horse's mouth; another very important thing for the rider to remember, is to always 
have his attention and mind on his horse and his surroundings. The trained horse should be ridden with both reins equally, and the untrained horse only with the snaffle; it is not often the bits that worry the horse, but the rider's hand. When wishing to stop a horse, do so gradually, but never suddenly, for you might strain your horse by doing so.

As I have explained to you before, some horses require to be handled differently to what others do, and one should always remember that fact. I hope that my readers will not think me too exacting or too pointed in my remarks, for I am not at all; but during the many years that I have had to do with horses and horsemen, I have secretly stored all the knowledge I could obtain, and always looked for points as regards riding and horses. When a boy, I had the good luck to be acquainted with some few of the best horsemen in the old world, and have hunted with them for several seasons. I used to meet boys about the same age as myself, young men and old men as well, and many a good word of advice has been given to me by men who had three score years or more over their heads and their hair as white as snow. I can safely say that I never once forgot the kindness extended to me by any of my friends in those days. What happy days they were to me, and the only thing to mar the sport was that I received so many spills; that is, had horses fall into ditches, striking their head on the opposite bank, and sending me to, I cannot remember where, 
to say nothing about getting run away with; my horses, upon those occasions, always got away, for I never had strength enough to hold them in. Many a day's sport I have had at the expense of a fractured limb, but I would give a great deal to go through it all again. Do not mistake me and think for a moment that I enjoy being run away with, for I do not, and that is the only time that I feel defeated and in anything but a happy mood. The excitement of the chase, the company you meet, and the house you belong to, seem to inspire a greater courage to dare to do what one has never done before. Speaking about runaways, that reminds me that I have been often asked by many what should a man do if a horse should run away with him. It is amusing to hear the remarks of some people as to what they should do. One man says run the horse into a fence. Now I will give you my advice. If a horse ran away with me, I should pray that he might take me to a better place than the one I had left. Now dear readers it is a very hard matter to say what any one would do in such a case, but it is easier to say what should be done. My advice is that if a horse should run away in the city, use all your strength to stop him before he runs very far, by taking hold of the snaffle reins in each hand, sawing hard at his mouth left and right, at the same time try and turn his head gradually to the left and then round to the right, the object in turning the horse's head is to try and get him off his stride, and every little while call out "whoa loy." If your horse 
should run away with you in a field, try and ride him on a circle, if in your power to do so, it will have a great effect on the horse, and if you keep riding round, gradually making the circle smaller, he will either stop or fall down. If out in the country the horse starts to run away, and the road is good, let him run, providing you are not afraid ; and if, when approaching a hill, the horse decides to stop at the foot of it, you must quickly change his plans by laying on the whip as hard as you can, and make him run faster than before, and when at the top you can stop him, and I venture to say that he will never run away again ; but after whipping him, do not pat him on any account, but speak sternly to him, then turn round and walk nearly all the way home. If you have time to ride on him the next day, do so, and take him over the same ground that you rode the day before, it is not at all likely that he will attempt to run away again.

When riding at a long distance from home, and if your horse should be so unfortunate as to cast a shoe, enquire for the nearest blacksmith and ride your horse slowly to the place then have the shoe nailed on. If you are riding on a school horse, the proprietor of the school will be only too glad to refund you the price of the shoe on your return. Never abuse your horse without just cause. Always remember that the longer you ride, the more you will have to learn. I think the horse is man's greatest teacher. If you should ride much you will find out that every horse is somewhat different to handle and 
manage. When riding down hill always walk your horse. If you should stop at any road house, even for a few minutes, have the man lead the horse about, and tell him to keep him moving until you call for him; but if you intend staying for some time, and having a long journey to go, give orders to have the horse put in the stable and blanketed, and when you are ready to leave, walk down to the stable and ask the man to give your horse a pail of water, that is providing the horse is quite cool and that his blood is not overheated before riding away; do not forget to reimburse the groom for his trouble, as it will always pay you to do so.

I wish to mention something more about road riding. Whenever you see that your horse is afraid of any object, try to divert his attention by playing with the bit in the horse's mouth, which in most cases will be successful. When riding on the road in a class, the riders should keep together and ride at a steady gait on the side of the road. The slow horse should set the pace for the rest. It is necessary to mention here a word or two with regard to politeness on the road. It is just as easy to be polite on the road on horseback, as it is in the drawing-room. A gentleman when riding with a lady, will always raise his hat when meeting any one he knows, and expects the same in return, but a great many men I have met in the park, instead of raising their hat as they should do, simply lift their whip up to their hat, like a groom tipping his cap to his mistress. 


\section{HANDS AND SEAT.}

There are many people who never obtain a good seat on horseback; the same may be said with regard to hands. I have been acquainted with some men and women who have ridden for years, and men who claim to be thorough horsemen, and in their own estimation, know all about riding, but have neither any seat nor good hands. Now what is the reason that so many people have such poor hands and seat? Is it because they are not taught correctly? No, that is not the reason, but it is because the rider is forgetful and careless, and very often nervousness is the trouble. There are some people who, if you asked them to ride a quiet-going, easy horse, could do so with credit, but if you asked one of them to ride a horse with a better mouth and better trained, and required light hands, nine cases out of ten it would result in failure.

I have found a great many men who think it a grand thing to bully their horse when riding him; they fancy that they are as strong as the horse, because they are able to sit on his back better than some others. Everything that they require the horse to do is demanded by brute force, and the poor beast is often made to attempt to do things which he finds he is unable to do. Such 
men have nut the patience or common sense to understand that the horse requires to be shown and instructed, and must be given time to learn.

Riders who have the best seats are they, whether men or women, whose tempers are good and who are in constant communication with their horses. A good rider always has a feeling of his horse's mouth, but never holds on by it; he can tell in an instant by the feel of the horse's mouth if he contemplates anything out of the way, and can nearly always forestall him in time. If the horse should get startled and jump to one side, he goes with him and does not pull his mouth about; in fact, it would appear that horse and man were one machine, possessed of one mind between them. If people who keep horses once are made to understand what riding means, and to know how agreeable is the feeling of a horse going pleasantly up to the bit without pulling, at the same time feeling, as it were, every motion of the horse, they would never be satisfied with one that was not thoroughly broken, and they would always try to keep him a perfect saddle horse.

The first thing then a rider must try to get is a good seat, and it must be in the proper place, that is, in the middle of the saddle, which is the only correct seat to have. The man that sits back on his saddle on the cantle, and has his legs bent forward has a chair seat, and the man who leans his body forward and sticks his legs out has a fork seat, and any man that rides the latter way 
is entirely at the mercy of the horse. As I said before, the only seat is in the middle of the saddle, the lower part of the leg about covering the girths, and the toe in line with the knee, the hips upward movable, in order to enable the rider to balance himself, and from the knee downward movable, so as to close the legs, and be able to use the spur when required to control the horse's hind legs. The rider must hold on by his thighs and knees, and must never depend on his reins or his heels, to hold him on. 


\section{LEAPING.}

WHEN training a horse to jump, the trainer should be very careful not to frighten the horse at the commencement, as every horse is a willing and natural jumper, and those horses that refuse are spoiled by bad training. For this reason one must be careful not to take the horse's own confidence, but teach the horse gradually, that means every young horse should be taught to jump at first without a rider. When he is so far advanced that he takes the obstacles with pleasure, the trainer mounts him and commences to jump low hurdles and small ditches, and be very careful not to disturb his mouth. At the beginning the young horse should be ridden with a plain snaffle, as all refusing more or less, is caused by fear that the bits will hurt his mouth, but I wish to make the remark that if a man thinks his horse fit for jumping, he has to be firm and decided, and force him over the jump.

\section{TRAINING.}

In the preceding chapters I have endeavored to explain to you how to ride in the ring, and how to ride on the road, and before finishing my book I wish to make a few remarks about training. It is necessary for 
a man to be a successful trainer, to have a love for a horse and to be able to keep his temper and to have plenty of courage. The trainer should never forget that he has to deal with an animal which cannot be broken by brutal force, but can be with patience, care and love. The great difficulty for an employed riding teacher in any of the schools in this country, that means if he is a man that understands his business, and one who has the ambition and will to instruct his pupils in the proper way, is that he does not find the material, simply because the horses are not thoroughly broken in the campaign school at first. It is a great mistake of many men who own horses to think that they can have them broken to the saddle in a month or two, as it is impossible to train a horse as one should be trained in a shorter time than three or four months without injury to the horse, because if any one should attempt to train a horse in a shorter time, it would not only injure the horse, but no good results would be obtained from it. If you want to train a horse in the proper way, you should take into consideration his age and his build, and never require more in one lesson than the horse can do with ease and without fatiguing him and thereby provoking his resistance. The training always commences by bringing the horse well in balance, for this reason the horse, for the first few lessons has to be ridden only at a walk and natural trot. After this, if the horse commences to gain confidence in his rider, you commence to make the turning first at a 
walk and then on the spot, at the same time the horse has to be made flexible in the jaw and in the neck, before and after each lesson.

Now we go over to balancing the horse, that means the horse has to be ridden for a certain time in a short, steady and even trot, the result will be that you will get the horse accustomed to go up to the hand and leg, for this reason you have to ride your horse well into the corners of the ring, also when trotting ride the turnings, changes and circles. When the horse does all of the above instructions correctly, it will be well to commence with the passages, which should always be done at first from the ground. (What is called passages?) It means that the horse goes on a double track. What are the passages? There is the full passage and the half passage, after this comes the shoulder in. You should always begin to train your horse first with haunches in. When the horse is properly placed in shoulder in, his body from head to tail should be curved. The head and shoulders leading. The inward legs crossing the outward on two parallel lines, the hind feet one yard from the side. Suppose that you wish to make the horse go right shoulder in, you first place the horse by feeling the right rein and closing the left leg, but the rider must be careful not to bring the forehand in too much. When he is in the proper position the right legr should be closed and the shoulders led off by the left rein, the bend being kept to the right, so that the horse will be gaining ground to his left, moving 
sicleways, though still bent and looking to his right. 'The left rein leads the horse and the right bends him; by a pressure of the right leg makes him cross his legs, and the left leg prevents him from running back, or hurrying away from the pressure of the right leg. The horse must not be allowed to hurry, and when wishing to stop, the left leg should be closed.

The difference between shoulder in and passage, is this: In the shoulder in the horse looks and bends the opposite way that he is going, whereas in the passage he bends and looks and goes the same way, and the horse turns on his forehand in shoulder in, while in the passage he turns on his haunches.

All the above instructions are given to bring the horse well in balance, to supple his neck, ribs and shoulders, and to teach him to obey the pressure of the legs. Now we come to the gallop. It is very important that the trainer in the first few lessons in the gallop does not irritate his horse, for this reason a young horse should always be instructed to start from the trot into the gallop, and always when he is in a natural position; that means when he passes the corner, or if the trainer brings him first in a circle. When the horse is so far advanced that he starts easy into a gallop, he should be started from haunches in from a walk. 


\section{ADVICE TO LADIES AND GENTLEMEN WHO INTEND BUYING A SADDLE HORSE.}

In the first place those intending to buy a horse have to make up their minds what kind of a horse they want to buy, so that they are perfectly satisfied after the purchase is made. When buying a saddle horse you have to be convinced either by yourself or by some good veterinary surgeon that the horse is sound. What is a sound horse? A horse is called sound when his four legs are clean, eyes perfect, wind good, and his bowels are in order. I will here describe a good saddle horse and tell you what is required to be a good one. To begin with, the horse's head should be lean and well cut out, he should have a broad and intelligent eye, a broad forehead and large nostrils. The ear should be small and pointed. A horse should have a long neck, well arched and well cut out in the jaw; he should have high withers, deep and sloping shoulders and broad chest. The front legs should be straight, the upper arm to the knee long and very muscular. The knee should be broad and flat, the cannon bone or shank should be short, strong, and flat. The pastern should not be long or short, standing oblique. The hoof should be deep and sound, that means 


\section{ADVICE TO LADIES AND GENTLEMEN. 5 I}

that the horn should be strong and clean, without any cracks, the one of the main points of a sound hoof, should be large and wide, touching the ground. A saddle horse should have a short back and be well ribbed up near the hips and strong across the kidneys. The haunches should be long, never cut off and very straight, the tail be set on high-standing straight out. The hocks should be large and bony and very strong, not close together nor far apart, but straight. In regard to fetlock and hoof they should be the same as front feet.

Question. What is the proper age to buy a saddle horse?

Answer A saddle horse should never be younger than five and never older than nine.

If you buy a young saddle horse be convinced that his gait is clean and not too long. With regard to a broken horse, be satisfied that he has not been spoiled, that he has no tricks or vices and that his gait is true and even. 


\section{SUGGESTIONS.}

HOW TO START AND HOW TO RUN A PUBLIC RIDING SCHOOL.

IF a man intends to start a public riding school, he must be decided where to locate it. A man with but little capital will always do better to start in a small, but thriving and growing town. In a city like New York or like cities, only a man with large capital can expect success.

Before you have made your mind up to build a school, you must be sure of a very good and convenient location. The main building in the stable should have all modern improvements and be well ventilated, and should therefore be made as comfortable as possible for the public. Before you open your school you must have a well selected and properly trained stock of horses and also the proper equipments, which under all circumstances should be kept neat and clean and in good order. If you should require the assistance of other riding masters, you should be very careful to select the proper men, but not adventurers in which all large cities abound.

Before you advertise in the daily papers the opening of your establishment, you must be sure that everything is in perfect order and in readiness, and at the same time 
when advertising your school, you should mention the rules which will be observed and carried out to the letter. To run such a place in the proper way it is important that from the start the proper system is kept. The riding masters should be treated like friends of their employer, not like hirelings. No bad feeling among themselves should exist or be tolerated, and such men as cannot agree should be discharged. The teachers should always work together hand in hand for their employer's interest. The foreman of a large riding school should be his employer's right hand man in many cases, and therefore not alone a thorough horseman, but a man of great experience, and should be able to control stable help and put such a spirit in his men that they do their work with pleasure and with readiness.

It is very important that the horses are divided equally among the riders, but under no consideration should the favorite horses be allowed to be overworked and ruined before their time. For this reason the proprietor of a riding school should never keep such horses as are useless to him and are not fit for work and stand idle in the stable, but should dispose of them at once.

As regards road-riding, it is very necessary to try and arrange to get together parties to ride out under the leadership of one of the masters, who is made strictly responsible for the horses. When this cannot be done, horses let out without a riding master should only be let out to well known patrons and pupils of the establish- 
ment, and even those should be warned not to abuse the horses, as in such a case it would be the proper thing to inform them that they cannot be supplied any more from the school.

According to the proper riding instruction, it will be always a great benefit to arrange as much as possible private classes, as it is natural that the progress in riding will be very beneficial to the pupil. 


\section{WHAT HORSEBACK RIDING HAS DONE: FOR}

\section{MANY, AND WHAT IT WILL DO FOR YOU.}

A GREAT many people have often asked me why it is that so many people ride. The answer briefly told, is this: There are several reasons why people ride, one is because they really enjoy it, and after a fair trial find that it is about the best pleasure in life ; another reason is that it is the most healthgiving exercise that there is, which is a very good reason. Another reason is because it is fashionable, but that seems to me a very poor reason to give, although many people cling to fashion like a drowning man does to a rope.

Question. Why should nearly every one ride on horseback?

It is because it is a duty to yourself and family. There are thousands of men to-day in New York who would be the better for horseback riding, men who are compelled to be in an office all day long and those who have more or less brain work to do, and then we have another class of men who are always ill at ease, ill in mind and ill in body, and such men remind me of a badger in a hole, that requires drawing out. The truth of the matter is that they need a tonic, and that is horse- 


\section{WHAT HORSE-BACK RIDING HAS DONE.}

back riding. Medicine has been tried and has failed. Forty-five doctors out of every fifty recommend horseback riding, and the other five are opposed to it, simply because they have not made a thorough study of the subject and their grounds for objection are based on their inexperience. I have, however, to acknowledge that the doctors are perfectly right in certain cases, to forbid their patients to ride.

Ladies should ride a great deal more than they do, as they do not get enough exercise as a general thing. What has riding done for a great many? It has made old men feel younger and made young men feel better. Remember the old saying, that "health is wealth." What will riding do for you? It will cure so many ills that I could not begin to write them all down, and it is the most healthgiving exercise that there is. A riding master who understands his profession thoroughly, when coming in contact with so many different people, will know at a glance what should be done with a timid person, in fact, a teacher has to study his pupils like a doctor does his patients. Some pupils can stand a great amount of exercise, while others can stand but very little, so it is the instructor's duty to remember that fact, and he should always try and make the lesson as pleasant and instructive to the pupil as lies in his power. The wealthy ride hecause it is a pleasure for them to do so, the middle class follow suit for the same reason, and some rive for health. The poor man rides whenever he has a dollar to spare. 
It is a great mistake to think that the expense is so much, for the prices for riding lessons are within the reach of nearly all who wish to indulge. Many people exclaim that they could never afford to ride, but they do not take time to think how much money they have to pay for medicine in a year, more than haif of which could be saved and be put to a better purpose Then again, a great many declare it to be a dangerous sport; it is no more dangerous than walking on the street when one is on a quiet horse. Now my friends do you think it benefits me in talking to you this way? Not at all, but as I know what benefit horseback riding has done myself and thousands of others, I feel that I am working for a good cause in asking you to learn to ride. There are a number of good schools in New York and in nearly every large city. If you cannot go to one, go to the other. My advice is to go and learn to ride on horseback, if it necessitates your having to go twenty miles. 


\section{SOME USEFUL TIPS.}

Never wash a horse with cold water when he is heated.

Water before feeding, but not while the horse is hot from work.

Feed your horse regularly three times daily, but never over feed.

Use the whip very little, and never when the animal shies or stumbles.

Give the horse a large stall and good bed at night. It is important that he lies down to rest.

If you own a horse that rears or stumbles, dispose of him as soon as you cals.

A cotton card is a good thing to groom a horse with. It cleans better than the comb.

Near the close of a journey let the horse walk. If he is covered with sweat, use a scraper, and then rub off with a rag to prevent too sudden cooling. 







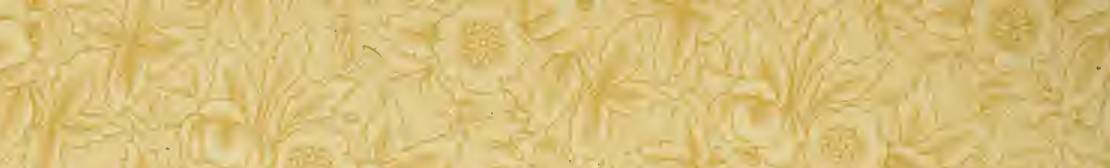

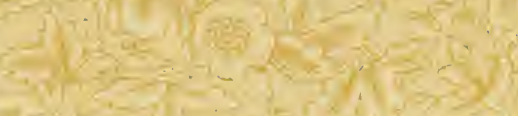

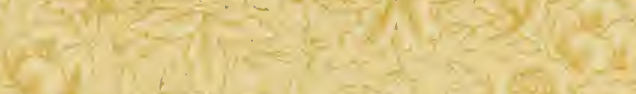

diry

Let

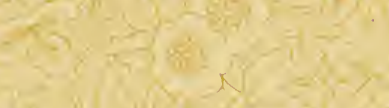

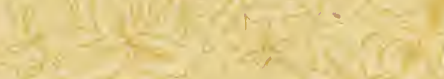

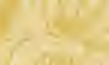

$x_{10}=$

$23 w^{-2}$

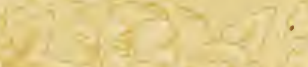

$\frac{2}{2}=1$

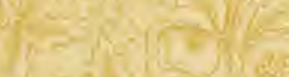

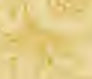

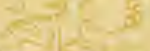

$\frac{2}{212}$

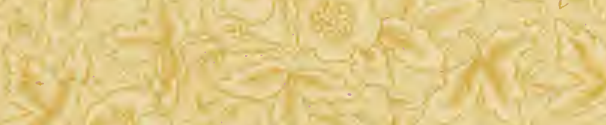

$301=2$

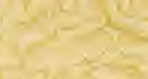

If $x<=5 y=$

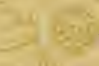

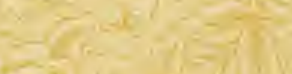

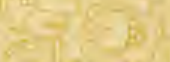

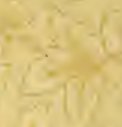

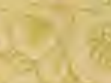

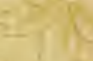

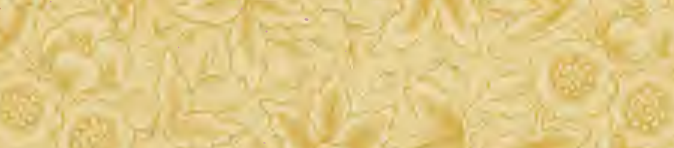

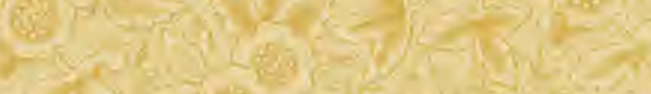

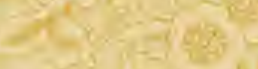

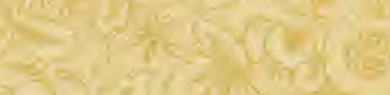

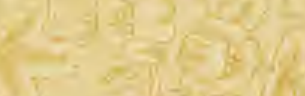

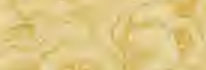$$
y^{8}-1
$$

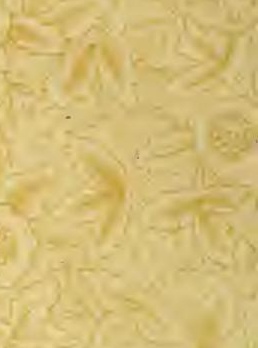




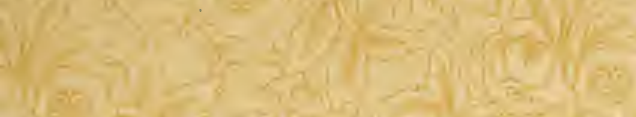

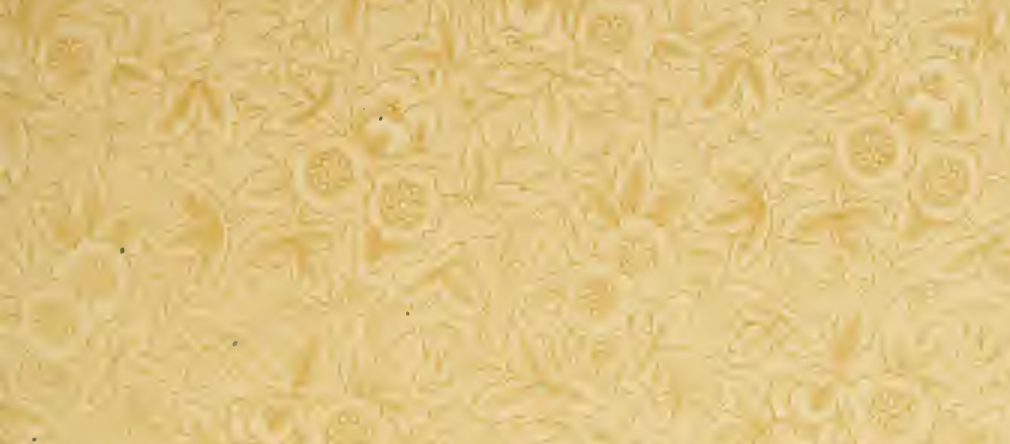

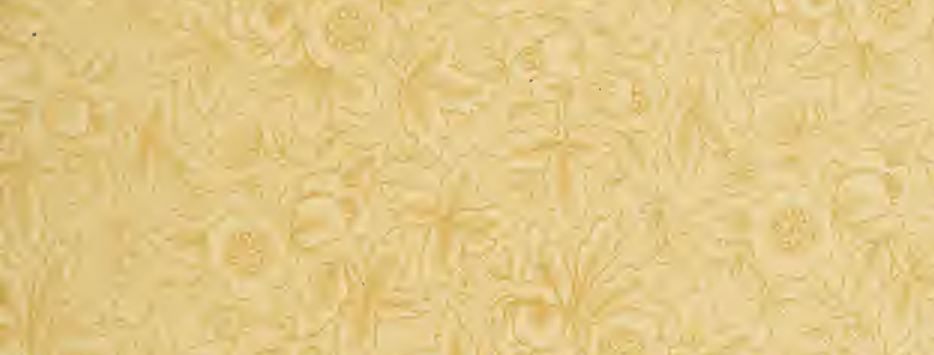

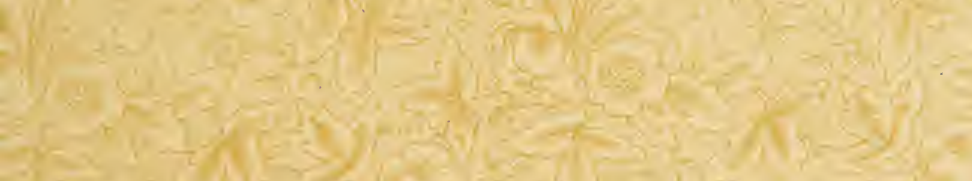

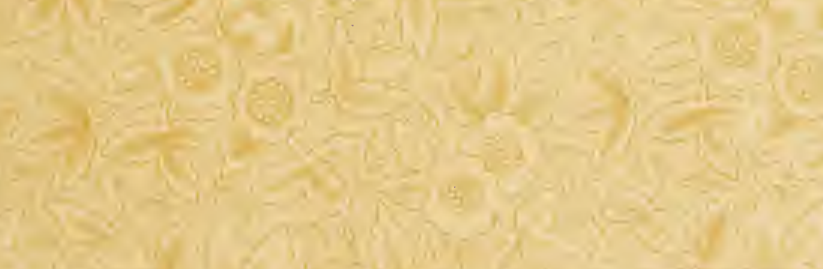

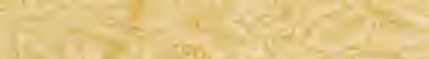

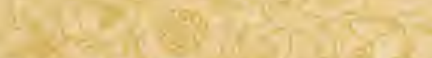

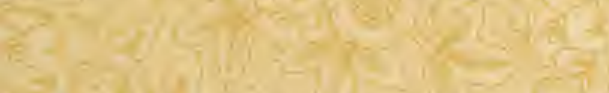

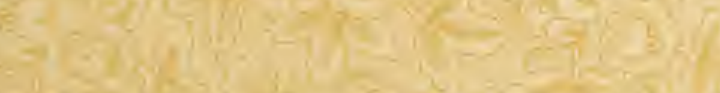

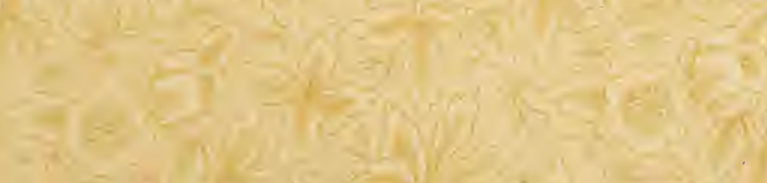


